American Journal of Agricultural and Biological Sciences 6 (1): 128-133, 2011

ISSN 1557-4989

(C) 2010 Science Publications

\title{
Vase Life Extension of Rose Cut Flowers (Rosa Hybirida) as Influenced by Silver Nitrate and Sucrose Pulsing
}

\author{
Mohy Eldeen Nour Eldaim Elgimabi \\ Faculty of Science, Taif University, Saudi Arabia, P.O.Box.888
}

\begin{abstract}
Problem statement: This experiment was carried out in the laboratory of the Department of the Biology, Taif University, Saudi Arabia. Approach: The study was conducted to investigated the silver nitrate $\left(\mathrm{AgNO}_{3}\right)$ and sucrose at different concentration on rose cut flowers longevity, which determined on the basis of wilting, chlorophyll retention and carbohydrate degradation .The treatments were, water control, 20, 30 or $50 \mathrm{ppm} \mathrm{AgNO}_{3}$ and sucrose at 1,2or 3\% w/v. Results: The results showed, flower vase life was prolonged by all $\mathrm{AgNO}_{3}$ treatments. The best concentration was $30 \mathrm{ppm}$ .The effect was further improved when $\mathrm{AgNO}_{3}$ was combined with $3 \%$ sucrose, which recorded the best vase life compared to other concentrations of sucrose .The per cent of wilting was minimized as result of using this combined treatment However the per cent of wilting increased with the increase in concentrations of $\mathrm{AgNO}_{3}$ and complete wilting occurred after 10, 8 and 7 days when treated with 20, 30 and $50 \mathrm{ppm}$ of $\mathrm{AgNO}_{3}$, respectively, while sucrose shortened the period to reach wilting. Also $\mathrm{AgNO}_{3}$ at $30 \mathrm{ppm}$ retarded the chlorophyll as well as carbohydrate degradation during the postharvest life. The experiments were repeated three times with three replicates and a completely randomized design had been used. The experiments extended from February, 2006-September, 2008. The difference between means was performed using Duncan multiple range test at 0.05 levels. Conclusion: A significant improvement in vase life of rose cut flowers was occurred when treated with $30 \mathrm{ppm}$ $\left(\mathrm{AgNO}_{3}\right)$ more effects when combined with 3\% (w/v) sucrose, so we recommended that to use the previous treatments with this concentrations for a long vase life and commercial productions.
\end{abstract}

Key words: Vase life, rose cut flowers, sucrose pulsing, carbohydrate degradation, randomized design, silver nitrate, bacterial proliferati, Rosa hybirida, chlorophyll determination

\section{INTRODUCTION}

Rose, a universally celebrated flower, has been used as a garden plant since the dawn of civilization. Rose is a symbol of perfection, elegance, romance and love. It was called "The Queen of Flowers" firstly by Greek poetess in her "Ode to the Rose" (Muhammad et al., 1996). Roses (Rosa hybirida) belong to family Rosaceae and Genus Rosa which contains more than 150 species and 1400 cultivars (Synge, 1971). Rose enjoys superiority over all other flowers being extensively used for decorative purposes and is prized for its delicate nature, beauty, charm and aroma. Rose is recognized for their high economic value, which are used in agro-based industry especially in cosmetics and perfumes. Additionally, roses play a vital role in the manufacturing of various products of medicinal and nutritional importance. However, the main idea of rose plant cultivation is to get the cut flowers, which greatly deals with the floricultural business (Butt, 2003).

Vase life of cut rose flowers is usually short. Cut flowers wilt and floral axis become bent (bent-neck) just below the flower head (Van Doorn et al., 1997). The development of such symptoms is considered to be caused by vascular occlusion, which inhibits water supply to the flowers (Loub and Van Doorn, 2004).

Several methods to increase the vase life of cut flowers and keep their freshness for longer periods have been reported. Cut flowers should be free of any deterioration, as this is one of the principal entry points for decay organisms (Hardenburg, 1968). A major form of deterioration in cut flowers is the blockage of xylem vessels by air and microorganisms that cause xylem occlusion (Hardenburg, 1968).

Silver nitrate $\left(\mathrm{AgNO}_{3}\right)$ is one of the most common forms of silver salts used in commercial flower preservatives solutions and mostly used as ethylene binding inhibitor. Pulsing with $\left(\mathrm{AgNO}_{3}\right)$ strikingly enhanced vase life and solution uptake in rose cut flowers (Singh and Tiwari, 2002). Also Darras et al. (2010) reported that, pulsing with 20 or $40 \mathrm{mg} \mathrm{L}^{-1}$ $\mathrm{AgNO}_{3}$ for $24 \mathrm{~h}$ extended vase life by 1.6 and 1.9 days, respectively, compared to the control.

Furthermore, treatment with germicides, such as silver nitrate (Ohkawa et al., 1999) or 8hydroxyqunoline sulfate (Gilman and Steponkus, 1972; Ichimura, 2003), inhibited bacterial proliferation and maintained the hydraulic conductance of stem. These 
findings suggest that bacterial proliferation is responsible for vascular occlusion, which shortens the vase life of cut rose flowers. Pulsing of cut roses for 1020 mint with $\mathrm{AgNO}_{3}$ improved the vase life up to 6.0 and 5.3 days, respectively (Reddy et al., 1988).

On other hand, sucrose pulsing increased the vase life of different cut flowers. Different concentrations of sucrose had been investigated by Butt (2005) on two cultivars of Rasa hybirida and results showed that sucrose at $25 \mathrm{gmL}^{-1}$ extended the vase life by 8.2 days in var. Whisk Mc and 7.5 days in var. Trika as compared to 5.3days in control (Butt, 2005). Also Pun et al. (2005) treated cut spry carnation by different concentrations of sucrose ranging from $0-7.5 \%$ and found that $5.0 \%$ sucrose recorded the best vase life and delayed the climacteric ethylene in petals. The vase life was more extended when added sucrose to the $\mathrm{AgNO}_{3}$. Furthermore, Cho and Lee (1980) study the effect of combination between these two chemical on cut rose $\mathrm{cv}$, Mary Devor and result in the vase life was doubled when treated with $3 \%$ sucrose+50 ppm $\mathrm{AgNO}_{3}$ compared to control. Also, pulsing with $\mathrm{AgNO}_{3}$ and sucrose + citric acid solution for $16 \mathrm{~h}$ was extended the vase life of rose cut flowers due to preventing the bentneck of flower stem (Halevy et al., 1978). Also addition of bactericides and fungicides in solution of $\mathrm{AgNO}_{3}$ and sucrose improved the flower size and largest buds opened in three days instead of five days; whereas, their vase life was four days greater than control (Nikolova and Koneazak, 1986).

\section{MATERIALS AND METHODS}

Site: The experiment site was University of Taif, laboratory of the Department of Biology, Saudi Arabia.

Plant materials: Cut flowers of roses were obtained from a commercial grower in Taif, Saudi Arabia. Flower stems were trimmed to $30 \mathrm{~cm}$ underwater to avoid air embolisms (Van Leperen et al., 2001). All leaves on the lower section of the stem were removed.

Treatment setting: Treatments were set following completely randomized design. Each treatment replicated by 3 replication.

Experiment (1): Silver nitrate $\left(\mathrm{AgNO}_{3}\right)$ was applied at concentrations of $0,20,30$ or $50 \mathrm{ppm}$.Sucrose was used at concentrations of $0,1,2$ or $3 \% \mathrm{w} / \mathrm{v}$. The two compounds were dissolved in sterilized distilled water in $250 \mathrm{~mL}$ bottle glass (Miyamoto et al., 1999). The sample had been divided into seven groups with three replications containing three flowers each. The flowers were kept at room temperature $\left(23+1^{\circ} \mathrm{C}\right)$ at normal day light and natural ventilation. Visual rating of flowers was carried out on the basis of a scale from 1-4 according to Hassan (2005) where: 1= entirely fresh flowers and $4=$ wilting in $50-100 \%$ of the petals.

Experiment (2): $\mathrm{AgNO}_{3}$ at $30 \mathrm{ppm}$ and sucrose at concentration $3 \%(\mathrm{w} / \mathrm{v})$ gave the best results in experiment (1). Hence, the effect of both concentrations of $\mathrm{AgNO}_{3}$ and sucrose on chlorophyll retention and carbohydrate degradation was further investigated.

Chlorophyll determination: Chlorophyll was extracted by methanol and absorbance was determined by a spectrophotometer on day 1,3 and 5, according to the method of Harborne (Nowak and Rudnicki, 1990). $\mathrm{Chl} \mathrm{a}$ and $\mathrm{Chl} \mathrm{b}$ were then calculated using the flowing equation:

Chl a $\left(m g 1^{-1}\right)=12.21 \mathrm{~A}_{663}-2.81 \mathrm{~A}_{646}$. Chl b $\left(\mathrm{mg} 1^{-1}\right)$ $=20.13 \mathrm{~A}_{646}-5.03 \mathrm{~A}_{663}$.

Carbohydrates determination: Carbohydrates were determined on the stems and petals of the best treatment of the two compounds. Samples were taken on day 1, 3 and 5 and separated by a High Performance Liquid Chromatography (HPLC) fitted with differential refractometer to detect fructose, glucose and sucrose in the different samples (Hassan, 2005).

\section{RESULTS}

Effect of $\mathrm{AgNO}_{3}$ and sucrose on vase life of rose cut flowers: The vase life of rose cut flowers was extended by the different concentrations of $\mathrm{AgNO}_{3}$ used in Table 1 and Fig. 1. The vase life was longer in $\mathrm{AgNO}_{3}$ at $30 \mathrm{ppm}$ which resulted in 8.97 days compared to other concentrations (Table 1). Sucrose resulted in the lowest vase life compared to $\mathrm{AgNO}_{3}$ at the different concentrations used. The longest vase life was attained when sucrose was applied at $3 \% \mathrm{w} / \mathrm{v}$, which gave 6 days in comparison to 5 days for control. However, the two compounds used significantly extended the vase life of rose cut flowers compared to control.

Table 2 showed that the per cent wilting increased with the increase in concentrations of $\mathrm{AgNO}_{3}$. The vase life was terminated on day 11, 10 and 9, when cut flowers were treated with 20,30 or 50 ppm 8-HQS, respectively compared to 6 days in control. Sucrose resulted in the lowest period to reach wilting per cent. Thus, wilting occurred on the 8th day after treatment with sucrose at different concentrations compared to 6 days in control (Table 2). 
Am. J. Agri. \& Biol. Sci., 6 (1): 128-133, 2011

Table 1:Effect of $\mathrm{AgNO}_{3}$ and sucrose on vase life of rose cut flowers (Rosa hybirida)

\begin{tabular}{ll}
\hline Treatment & Vase life (days) \\
\hline $\mathrm{AgNO}_{3} 20 \mathrm{ppm}$ & $9.30 \mathrm{~b}$ \\
$\mathrm{AgNO}_{3} 30 \mathrm{ppm}$ & $10.97 \mathrm{a}$ \\
$\mathrm{AgNO}_{3} 50 \mathrm{ppm}$ & $7.97 \mathrm{c}$ \\
Sucrose $1 \%$ & $5.77 \mathrm{ef}$ \\
Sucrose 2\% & $5.97 \mathrm{e}$ \\
Sucrose 3\% & $7.07 \mathrm{~cd}$ \\
Control & $4 \mathrm{f}$ \\
\hline
\end{tabular}

${ }^{1}$ : Different letters indicate the significant differences between means, according to Duncan multiple range $\mathrm{p}=0$

Table 2: Calculation of per cent wilting in rose cut flowers treated with different concentrations of $\mathrm{AgNO}_{3}$ and sucrose compared to control

Per cent of wilting in the different concentrations of 8HQS and sucrose ${ }^{1}$

\begin{tabular}{|c|c|c|c|c|c|c|c|}
\hline \multirow{2}{*}{$\begin{array}{l}\text { Days after } \\
\text { treatments }\end{array}$} & \multicolumn{3}{|c|}{$\begin{array}{l}\mathrm{AgNO}_{3} \text { conc. } \\
\text { (ppm) }\end{array}$} & \multicolumn{3}{|c|}{$\begin{array}{l}\text { Sucrose conc. } \\
\%(\mathrm{w} / \mathrm{v})\end{array}$} & \multirow{2}{*}{$\begin{array}{l}\text { Contro } \\
0\end{array}$} \\
\hline & 20 & 30 & 50 & 1 & 2 & 3 & \\
\hline 2 & 1.0 & 0.1 & 2.9 & 3.9 & 3.6 & 2.4 & 3.6 \\
\hline 4 & 14.5 & 11.3 & 15.5 & 26.2 & 25.3 & 22.6 & 54.9 \\
\hline 6 & 25.9 & 25.5 & 38.3 & 74.3 & 56.6 & 61.9 & 93.2 \\
\hline 8 & 91.6 & 50.6 & 79.7 & 93.3 & 94.8 & 92.3 & - \\
\hline 10 & 98.0 & 82.3 & 93.8 & - & - & 97.5 & - \\
\hline 11 & - & 96.3 & - & - & - & - & - \\
\hline 12 & - & 96.5 & - & - & - & - & - \\
\hline
\end{tabular}

${ }^{1}$ : Reading of per cent wilting was done every two days after treatments

Table 3:Effect of the best treatment of $\mathrm{AgNO}_{3}$ and sucrose on vase life and postharvest quality of rose cut flowers

\begin{tabular}{ll} 
Treatments & Vase life values (day) \\
\hline $\mathrm{AgNO}_{3} 30 \mathrm{ppm}$ & $12.5 \mathrm{~b}$ \\
$\mathrm{AgNO}_{3} 30 \mathrm{ppm}+3 \%$ sucrose & $14.5 \mathrm{a}$ \\
Sucrose 3\% & $7 \mathrm{c}$ \\
Control treatment & $5 \mathrm{~d}$ \\
\hline
\end{tabular}

Letters explain the significant differences between means, according to Duncan multiple range $\mathrm{p}=0.05$

Effect of the best treatment for $\mathrm{AgNO}_{3}$ and sucrose on vase life and postharvest quality of rose cut flowers: Results of Table 3 showed that treatment by $\mathrm{AgNO}_{3}$ at $30 \mathrm{ppm}$ prolonged the vase life of rose cut flowers with or without sucrose compared to control. When sucrose was added to $30 \mathrm{ppm} \mathrm{AgNO}_{3}$ the vase life was extended to 12 days compared to 9 days without sucrose. However, sucrose at $3 \%$ extended the vase life by 7 days compared to 6 days only in control (Table 3).

Chlorophyll content: The previous treatments lead to a considerable delay in degradation of $\mathrm{Chl}$ a and $\mathrm{Chl} b$ compared to control (Table 4). The concentration of chlorophyll a was higher than chlorophyll b at any point of time throughout the vase life. When flowers were treated with AgNO3 $30 \mathrm{ppm}$ chlorophyll content on the 1 st day was $0.672,0.330 \mathrm{mg} 1-1$ weight for chl. a and chl. b, respectively (Table 4).

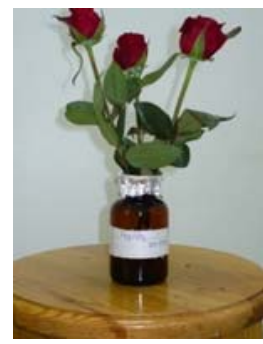

(a)

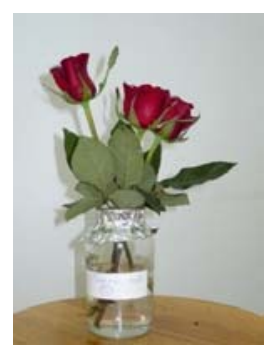

(d)

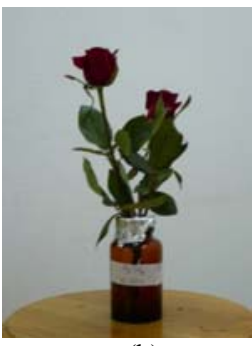

(b)

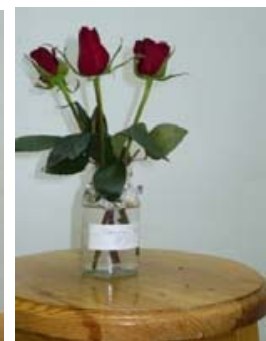

(e)

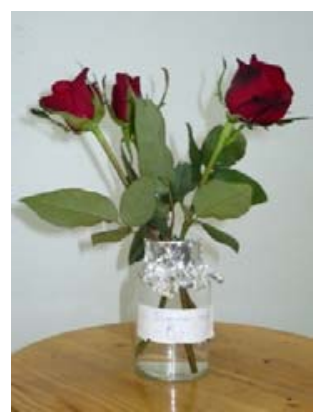

(g)

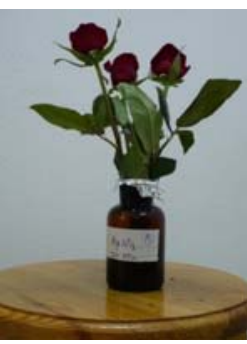

(c)

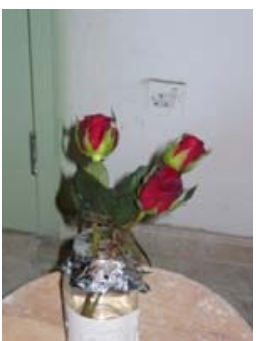

(f)
Fig. 1: Effect of $\mathrm{AgNO}_{3}$ and sucrose on vase life of rose cut flowers (Rosa hybirida) (a) $\mathrm{AgNO}_{3} 20$ ppm (b) $\mathrm{AgNO}_{3} 30$ ppm (c) $\mathrm{AgNO}_{3} 50$ ppm (d) Sucrose $1 \%$ (e) sucrose $2 \%$ (f) sucrose $3 \%$ (g) control

When sucrose at $3 \%$ was added chlorophyll content increased. Thus, at the end of the experiment the accumulated chl. A and chl. b, were 1.762, $0.391 \mathrm{mg}^{-1}$, respectively (Table 4).

Carbohydrate content: Data of Table 5 and 6 show that fructose, glucose and sucrose were the main soluble carbohydrates in petals and stems of cut roses. Fructose was the major component in the petals as well as in stems but, generally, its value was higher than in stems. Sucrose contents in petals and stems were lower than those of glucose.

The carbohydrate content significantly increased as a result of using $30 \mathrm{ppm} \mathrm{AgNO}_{3}+3 \%$ sucrose till the 3rd day then sharply decreased on the 5th day at which the vase life of control was terminated. 
Am. J. Agri. \& Biol. Sci., 6 (1): 128-133, 2011

Table 4: Effect of $\mathrm{AgNO}_{3}$ with or without sucrose and sucrose alone on chlorophyll content for rose cut flowers.

\begin{tabular}{|c|c|c|c|c|c|c|}
\hline \multirow[b]{2}{*}{ Treatments } & \multicolumn{6}{|c|}{ Days of determination of chl. $a^{1}$ and chl. $b^{1}$} \\
\hline & $\begin{array}{l}\text { 1st day } \\
\text { Chl. a }\end{array}$ & $\begin{array}{l}\text { 3rd day } \\
\text { Chl. b }\end{array}$ & $\begin{array}{l}\text { 5th day } \\
\text { Chl. a }\end{array}$ & Chl. b & Chl. a & Chl. b \\
\hline $\mathrm{AgNO}_{3} 30 \mathrm{ppm}$ & 0.727 & 0.384 & 2.402 & 0.541 & 1.757 & 0.521 \\
\hline $\mathrm{AgNO}_{3} 30 \mathrm{ppm}+$ sucrose $3 \%$ & 0.743 & 0.400 & 1.912 & 0.482 & 2.299 & 0.407 \\
\hline Sucrose $3 \%$ & 0.733 & 0.410 & 1.421 & 0.743 & 0.687 & 0.186 \\
\hline Control treatment & 0.727 & 0.384 & 2.940 & 0.406 & 0.596 & 0.070 \\
\hline
\end{tabular}

${ }^{1}$ : mg $1^{-1}$ fresh weight

Table 5: Effect of $\mathrm{AgNO}_{3}$ with or without sucrose and sucrose alone on carbohydrate content (in $\mathrm{mg}^{-1}$ dry weight) for petals of rose cut flowers

\begin{tabular}{|c|c|c|c|c|c|c|c|c|c|}
\hline \multirow[b]{3}{*}{ Treatment } & \multicolumn{9}{|c|}{ Days of determination of carbohydrate content } \\
\hline & \multicolumn{3}{|l|}{ 1st day } & \multicolumn{3}{|l|}{ 3rd day } & \multicolumn{3}{|l|}{ 5th day } \\
\hline & Fructose & Glucose & Sucrose & Fructose & Glucose & Sucrose & Fructose & Glucose & Sucrose \\
\hline $\mathrm{AgNO}_{3} 30 \mathrm{ppm}$ & 1.48 & 1.22 & 0.04 & 1.58 & 1.24 & 0.07 & 2.73 & 1.91 & 0.76 \\
\hline $\mathrm{AgNO}_{3} 30 \mathrm{ppm}+$ sucrose $3 \%$ & 2.99 & 2.01 & 0.89 & 2.27 & 1.79 & 1.03 & 3.71 & 2.03 & 1.93 \\
\hline Sucrose 3\% & 3.35 & 1.97 & 0.93 & 2.99 & 1.55 & 0.22 & 1.37 & 1.08 & 0.32 \\
\hline Control & 0.33 & 0.09 & 0.16 & 1.11 & 0.30 & 0.18 & 3.71 & 1.97 & 0.91 \\
\hline
\end{tabular}

Table 6: Effect of $\mathrm{AgNO}_{3}$ with or without sucrose and sucrose alone on carbohydrate content (in $\mathrm{mg}^{-1}$ dry weight) for stems of rose cut flowers

\begin{tabular}{|c|c|c|c|c|c|c|c|c|c|}
\hline \multirow[b]{3}{*}{ Treatment } & \multicolumn{9}{|c|}{ Days of determination of carbohydrate content } \\
\hline & \multicolumn{3}{|l|}{ 1st day } & \multicolumn{3}{|l|}{ 3rd day } & \multicolumn{3}{|l|}{ 5th day } \\
\hline & Fructose & Glucose & Sucrose & Fructose & Glucose & Sucrose & Fructose & Glucose & Sucrose \\
\hline $\mathrm{AgNO}_{3} 30 \mathrm{ppm}$ & 4.00 & 0.31 & 1.40 & 4.09 & 0.33 & 1.46 & 5.17 & 0.62 & 1.76 \\
\hline $\mathrm{AgNO}_{3} 30 \mathrm{ppm}+$ sucrose $3 \%$ & 1.33 & 1.55 & 0.03 & 1.44 & 1.67 & 0.05 & 1.77 & 4.58 & 0.09 \\
\hline Sucrose $3 \%$ & 1.37 & 1.08 & 0.32 & 1.66 & 1.23 & 0.44 & 2.00 & 1.87 & 0.61 \\
\hline Control & 0.91 & 0.30 & 0.08 & 0.99 & 0.60 & 0.11 & 1.01 & 0.18 & 0.24 \\
\hline
\end{tabular}

The concentrations of fructose, glucose and sucrose in rose petals were $0.65,0.18$ and $0.26 \mathrm{mg} \mathrm{g}^{-1}$ dry weight in controls at the end of the experiments (Table 5). At the same time values of these sugars in $\mathrm{mg} \mathrm{g}^{-1} \mathrm{dry}$ weight when petals were treated with $30 \mathrm{ppm} \mathrm{AgNO}_{3}$ and $30 \mathrm{ppm} \mathrm{AgNO}_{3}+$ sucrose $3 \%$ and sucrose 3\% alone were $1.96,1.26$ and 0.17 , respectively(Table 5).

While stem contents of the previous sugars increased at the beginning of the experiment, then decreased towards the end of the experiment compared to control (Table 6).

\section{DISCUSSION}

Silver nitrate $\left(\mathrm{AgNO}_{3}\right)$ is very potent inhibitors of ethylene action in plant tissues. The treatment of $\mathrm{AgNO}_{3}$ my be decreased the ethylene production by rose cut flowers tested in comparison to control .It is also provides some antimicrobial activity inside the plant tissues, thus its beneficial for ethylene sensitive flowers such as carnation (Nowak and Rudnicki, 1990).This might explain the effective role of $\mathrm{AgNO}_{3}$ in prolonging the vase life of rose cut flowers (Table 1) In addition, under $\mathrm{AgNO}_{3}$ treatment the percentage of wilting, chlorophyll and carbohydrate degradation was minimized an as a consequence, the vase life was extended (Table 2). These result are in harmony with the result of Singh and Tiwari (2002); Harode et al. (1993) and Reddy et al. (1988).

It is well known that sucrose supply increases the longevity of many cut flowers, since sucrose can act as a source of nutrition for tissues approaching carbohydrate starvation, flower opening and subsequent water relations (Kuiper et al., 1995), similar finding were obtained by Lalonde et al. (1999); Nichols (1973); Ichimura (Ichimura, 1998) and Downs (1988).

Concerning the role of sucrose with $\mathrm{AgNO}_{3}$ in the previous results show that adding sucrose extended the vase life and improved the quality of rose cut flowers. The data on of chlorophyll and carbohydrate contents show the positive role of $\mathrm{AgNO}_{3}$ with or without sucrose and sucrose individually on preserving the leaves in good condition by lowering the per cent of wilting and inhibiting the chlorophyll and carbohydrate degradation, similar result were obtained by Serek et al. (1996). Even in absence of exogenous ethylene, the life of the lowers was significantly increased by inhibiting ethylene action. As a similar tendency, Bartoli et al. (1997) and WeiMing et al. (1997) reported that. 


\section{CONCLUSION}

A significant improvement in vase life of rose cut flowers was occurred when treated with $30 \mathrm{ppm}$ silver nitrate and the effect was further improved when sliver nitrate at $30 \mathrm{ppm}$ combined with $3 \%$ (w/v) sucrose which attained the best result compared to other concentrations of sucrose. Also the per cent of wilting was minimized , beside chlorophyll as well as carbohydrate degradation had been retarded during the postharvest life as the result of using this combination treatment.

\section{REFRENCES}

Bartoli, C.G., G. Juan and M. Edgrdo, 1997. Ethylene production and responses to exogenous ethylene in senescing petals of Chrysanthemum morifolium RAM cv. Unsei. Plant Sci., 124: 15-21. DOI: 10.1016/S0168-9452(97)04582-2

Butt, S.J., 2003. A Review on prolonging the vase life of Roses. Pakistan Rose Annual. Published by Pakistan National Rose Society, pp: 49-53.

Butt, S.J., 2005. Extending the vase life of roses (Rosa hybirida) with different preservatives. Int. J. Agricul. Biology, 7: 91-99.

Cho, H.K. and J.M. Lee, 1980. Studies on extending the vase life of cut flowers of rose and carnation with various chemical preservatives. J.KSHS, 20: 106-110.

Darras, A., A. Loannidou and N. Pompodakis, 2010. Evaluation and improvement of post-harvest performance of cut Viburnum tinus inflorescence. Sci. Hortic., 124: 376-380. DOI: 10.1016/j.scienta.2010.01.018

Downs, C.G., 1988. Bud-opening treatments to improve Gypsophila quality after transport. Sci. Hort., 34: 301-310. DOI: 10.1016/0304-4238(88)90103-3

Synge, P.M., 1971. The dictionary of rose in color. 1st Edn., Madison Square Press, New York, ISBN-10: 0448025043, pp: 191.

Gilman, K.F. and P.L. Steponkus, 1972. Vascular blockage in cut roses. J. Am. Soc. Hort. Sci., 97: 662-667.

Halevy, A.H., T.G. Byme, A.M. Kofranek, D.S. Famham and J.F.B. Thompson et al., 1978. Evaluation of postharvest handling methods for transcontinental truck shipment of cut carnations, chrysanthemum and roses. J. ASHC, 103: 151-155.

Hardenburg, R.E., 1968. The commercial storage of fruits, vegetables and florist and nursery stock. Intrafinity

Corporation. http://www.msue.msu.edu/workspaces/one.cfm?wo rkspace_id=213590\&object_id=284535\&tab=objec t_view
Harode, S.M., V.G. Kotake and J.P. Zend, 1993. Effects of selected treatments on longevity and freshness of selected flowers in home decoration. J. Maharshtra Agricul. Univ., 18: 448-450.

Hassan, F., 2005. The Forgotten Museums of Egypt. Mesuem Int., 57: 42-48. DOI: 10.1111/j.14680033.2005.00509.x

Ichimura, K. et al., 2003. Shortage of soluble carbohydrates is largely responsible for short vase life of cut 'Sonia' rose flowers. J. Japan. Soc. Hort. Sc., 72: 292-298.

Ichimura, K., 1998. Improvement of postharvest life in several cut flowers by the addition of sucrose. Japan Agric. Res. Q., 32: 275-280.

Kuiper, D., S. Ribots, H.S. Van Reen and N. Marissenn, 1995. The effect of sucrose on the flower bud ripening of "Madelon: Cut roses. Sci. Hort., 60: 325-336.

Lalonde, S., E. Boles. H. Hellmann, L. Barker and J.W. Patrick et al., 1999. The dual function of sugar carriers: Transport and sugar sensing. Plant Cell, 11: 707-726.

Loub, M. and G. Van Doorn, 2004. Wound-induced and bacteria-induced xylem blockage in roses, Astible, and Viburmum. Hort. Sci., 32: 281-288.

Miyamoto, M., K. Inoue and Y. Gu, 1999. Effectiveness of acidic oxidative potential water in preventing bacterial infection in islet transplantation. Cell Transpl.. 8: 405-411. PMID: 10478721 http://www.ncbi.nlm.nih.gov/pubmed/10478721

Muhammad, S.M., S. Hiroyasu and N. Shahzad, 1996. Diversity in roses. Nat. Agric. Res. Center, Islamabad, pp: 1-2.

Nichols, R., 1973. Senescence of cut carnation flowers: respiration and sugar status. J. Hort. Sci., 8: 111-121.

Nikolova, N. and I. Koneazak, 1986. Development of tight greenhouse rose buds into flowers on an artificial medium. Acta Hort, 167: 435-440.

Nowak, J. and R.M. Rudnicki, 1990. Postharvest Handling and Storage of Cut Flowers, Florist, Greens and Potted Plants. 1st Edn., Timber Press, Inc., ISBN-10: 0881921564, pp: 210.

Ohkawa, K., Y. Kushhara and J.N. Suh, 1999. Mobility and effects on vase life oof silver-containing compounds in cut rose flowers. Hortscience, 34: 112-113.

Pun, U.K., H. Shimizu, K. Tanase and K. Ichimura, 2005. Effect of sucrose on ethylene biosynthesis in cut spray carnation flowers. Acta Hort., 669: 171-174.

Reddy, T., C. Nagarajaiah and B. Raju, 1988. Impregnating cut rose stem with nickel increases in vase life. Hort. Abst., 59: 2360. 
Serek, M., E. Sisler and M. Reid, 1996. Ethylene and the postharvest performance of miniature roses. Acta Hort., 424: 145-150.

Singh, A.K. and A.K. Tiwari, 2002. Effect of pulsing on postharvest life of Rose v. Doris Tystermann. South-Indian-Hort., 50: 140-144.

Van Doorn, W.G., Y. Witte, W.G. Van Doorn and Y. De-Witte, 1997. Sources of the bacteria involved in vascular occlusion of cut rose flowers. J. Am. Soc. Hort. Sci., 122: 263-266.
Van Leperen, W., J. Nijsse, C.J. Keijzer and U. Van Meetern, 2001. Induction of air embolism in xylem conduits of pre-defined diameter. J. Experimental Botany, 52: 981-991. DOI: 10.1093/jexbot/52.358.981

WeiMing, G., W. Zeng and F. Chen, 1997. Regulation of ethylene on senescence of cut chrysanthemum flower. J. Nanjing Agric. Univ., 20: 24-29. 